\title{
Hepatitis B or non-A, non-B virus infection in multitransfused thalassaemic patients
}

\author{
G A MORONI, G PIACENTINI, S TERZOLI, G JEAN, AND G MASERA
}

Blood Transfusion Centre, Clinical Institute of Perfezionamento, Departments of Paediatrics, St Gerardo's Hospital, Monza and the University of Milan; and Department of Medicine, Melzo Gorgonzola Hospital, Italy

SUMMARY We undertook a four year study of 128 thalassaemic patients who had undergone several transfusions, to determine the incidence of hepatitis B virus markers and the activities of transaminases in their sera each month. The results showed that the possibility of these patients contracting hepatitis B virus infection is still high, although on only one occasion was a transient antigenaemia found, indicating low viral replication. Furthermore, the probability of contact with hepatitis B virus increases with the number of transfusions and, therefore, with age. About $25 \%$ of these patients were positive for hepatitis B markers and $80 \%$ for other hepatitis markers including the case of cytomegalovirus hepatitis.

It has been known for some time that multitransfused thalassaemic patients are at high risk of contracting hepatitis $\mathrm{B}$ virus infection. ${ }^{1-3}$ This risk has been reduced considerably by screening blood donors for hepatitis B virus surface antigen, using radioimmunoassay. Where there is a medium or high incidence of asymptomatic carriers, however, such as in Italy and other Mediterranean countries, where the percentage of post-transfusion hepatitis B infection (three per cent) is still such that it cannot be disregarded, most cases of post-transfusion hepatitis are attributable to non-A, non-B virus. ${ }^{45}$ Cytomegalovirus hepatitis does occur, but in a negligible percentage. Post-transfusion hepatitis together with iron accumulation play an important part in the onset and evolution of liver disease in thalassaemic patients; their exact role is still, however, unknown. ${ }^{6}$

The aim of our study was to evaluate the prevalence and evolution of hepatitis $B$ and non-B viruses by means of a serial study of hepatitis $B$ virus markers in 128 multitransfused thalassaemic patients during a four year observation period.

\section{Material and methods}

Between August 1979 and August 1983, 128 thalassaemic patients were studied ( 65 boys and 63 girls; age range 0 to 20 years). Samples of serum were taken monthly from all the patients at the time of transfusion treatment and were tested for hepatitis B surface antigen and antibody, hepatitis B core antibody, and hepatitis B e antibody and antigen using solid phase radioimmunoassay (Abbott, USA); serum alanine and aspartate transferase and alkaline phosphatase activities and bilirubin concentrations were determined with standard methods. Activities of five times higher than normal were considered to indicate acute hepatitis.

When activities of transaminase were raised the patients' sera were also tested for IgM cytomegalovirus antibody, Epstein-Barr virus antibody (Enzygnost Citomegalia ELISA-Cellognost Mononucleosis IHA, Istituto Bhering, Italy), IgM hepatitis B core antibody, and IgM hepatitis A antibody (Abbott).

One hundred patients were monitored for four years, and the remaining 28 patients (who had started treatment later) were followed for at least six months.

Patients were transfused with leukocyte poor or leukocyte deprived (with Erypur filters, Organum Technica) red cell concentrates which were donated by voluntary donors who had been hepatitis B surface antigen negative at radioimmunoassay screening. A sample of 1557 voluntary blood donors were screened serologically in August 1982.

Most of the patients underwent chelating treatment consisting of desferrioxamine $(40 \mathrm{mg} / \mathrm{kg})$ given by continuous subcutaneous infusion pump for eight hours five days a week. 


\section{Results}

The incidence of hepatitis B virus markers in the 100 patients followed for four years is given in Table 1. At the start of the study only one patient was positive for hepatitis $B$ surface antigen and hepatitis $B$ e antibody and four were positive for hepatitis B surface antibody, hepatitis B core antibody, and hepatitis B e antibody (indication of recent infection). Seventy four were positive for hepatitis B core antibody or hepatitis B surface antibody, or both (previous hepatitis B virus infection), and 21 were negative for all the hepatitis B virus markers. At the end of the four years the number of patients negative for hepatitis B virus markers had decreased from 21 to 12 , the number of patients with antibodies had increased, and the one subject who was hepatitis B surface antigen positive at the beginning was still positive.

The figure shows the serologic findings at the end of the study for all the patients subdivided according

Table 1 Incidence of hepatitis B virus markers in 100 multitransfused thalassaemic patients between 1979 and 1983

\begin{tabular}{lcc}
\hline & $\begin{array}{l}\text { August } 1979 \\
(n=100)\end{array}$ & $\begin{array}{l}\text { August 1983 } \\
(n=100)\end{array}$ \\
\hline HBsAg+, anti-HBe+, anti-HBc+ & 1 & 1 \\
Anti-HBc+, anti-HBs+, anti-HBe+ & 4 & 7 \\
Anti-HBc+, anti-HBs+ & 43 & 50 \\
Anti-HBs+ & 24 & 28 \\
Anti-HBc+ & 7 & 2 \\
Negative & 21 & 12 \\
\hline
\end{tabular}

HBsAg=hepatitis B surface antigen; anti-HBe=hepatitis B e antibody; anti$\mathrm{HBc}=$ hepatitis $\mathrm{B}$ core antibody; anti-HBs=hepatitis $B$ surface antibody; $+=$ positive.

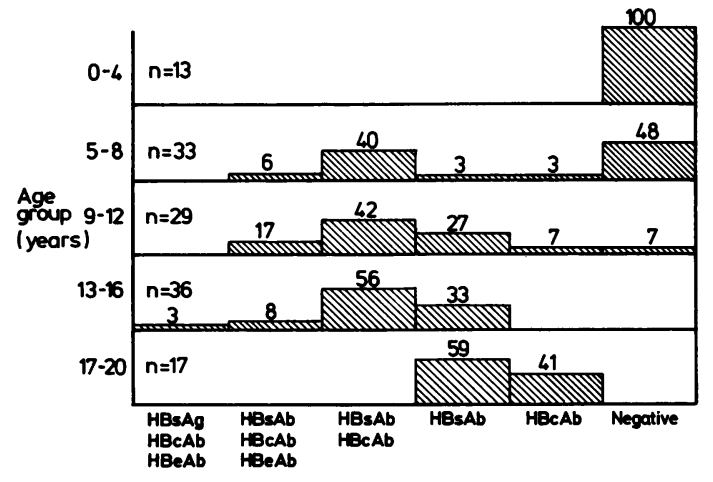

Figure Hepatitis $B$ virus markers in 128 multitransfused thalassaemic patients according to age group (\%)

HBsAg=hepatitis B surface antigen; $H B s A b=$ hepatitis B surface antibody; $\mathrm{HBCAB}=$ hepatitis $\mathrm{B}$ core antibody; $\mathrm{HBeAb}=$ hepatitis $\mathrm{B}$ e antibody. to age group. The 28 patients who entered the study after it started are also included. No antibodies associated with hepatitis $B$ virus were found in patients under 4 years of age but all those aged over 12 years had virus markers. Fifty three older patients had been transfused before the days when donors were tested for hepatitis B surface antigen.

Post-transfusion hepatitis was observed in 32 of the 128 children (asymptomatic in 31 , icteric in one) (Table 2). Hepatitis B surface antibody, hepatitis B core antibody, and hepatitis B e antibody were detected in only eight of these patients, immediately after the rise in the activities of alanine and aspartate transferases, showing that the hepatitis was caused by hepatitis B virus. A transient hepatitis $B$ surface antigenaemia was noted in only one of these patients. The remaining 24 patients, negative for all hepatitis B virus markers, were assumed to have non-A, non-B hepatitis; one of them was positive for IgM cytomegalovirus antibody.

Results of serologic screening of 1557 voluntary blood donors performed in August 1982 are shown in Table 3.

\section{Discussion}

Our study shows that multitransfused thalassaemic patients are at high risk of contracting posttransfusion hepatitis. The careful selection of bloods donors, however, has reduced noticeably the incidence of hepatitis B compared with the period 1970-9 when four of 47 patients showed transient positivity for hepatitis $B$ surface antigen and five icteric hepatic episodes were observed. ${ }^{7}$

The possibility of contact with hepatitis $B$ virus

Table 2 Incidence of hepatitis shown by raised concentrations of transaminases in multitransfused thalassaemic patients

\begin{tabular}{|c|c|}
\hline $\begin{array}{l}\text { Total } \\
\text { (a) Patients with no appreciable } \\
\text { increase in serum alanine } \\
\text { and aspartate transferase } \\
\text { concentrations }\end{array}$ & $\begin{array}{r}128 \\
96\end{array}$ \\
\hline $\begin{array}{l}\text { (b) Patients with } \geqslant \text { appreciable } \\
\text { increases in serum alanine and } \\
\text { aspartate transferase concentrations }\end{array}$ & 32 \\
\hline $\begin{array}{l}\text { Hepatitis } B \\
\text { Anti-HBs, anti-HBc, } \\
\text { and anti-HBe, including } \\
\text { one episode of transient } \mathrm{HBs} \\
\text { antigenaemia }\end{array}$ & $8(25 \%)$ \\
\hline $\begin{array}{l}\text { Hepatitis non- } B \\
\text { No subsequent seroconversion, } \\
\text { including one episode of } \\
\text { cytomegalovirus hepatitis }\end{array}$ & $24(75 \%)$ \\
\hline
\end{tabular}


Table 3 Results of screening for hepatitis B virus markers in 1557 blood donors

\begin{tabular}{|c|c|c|c|c|c|c|}
\hline No. & $\%$ & $H B s A g$ & Anti-HBs & $A n t i-H B c$ & $H B e A g$ & Anti-HBe \\
\hline 170 & $10 \cdot 9$ & - & + & + & - & + \\
\hline 235 & $15 \cdot 1$ & - & + & + & - & - \\
\hline 110 & $7 \cdot 0$ & - & + & - & - & - \\
\hline 62 & 4 & - & - & + & - & - \\
\hline 944 & $60 \cdot 6$ & - & - & - & - & - \\
\hline
\end{tabular}

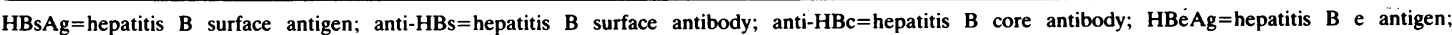
anti-HBe=hepatitis $B$ e antibody, $+=$ positive; $-=$ negative

remained high and seroconversion was rapid: only once could a transient surface antigenaemia be found, probably due to low viral replication. In contrast there was a noticeable and prolonged increase in the activity of the transaminases (4 to 8 months).

Of the blood donors, $39.2 \%$ were positive for hepatitis $\mathrm{B}$ virus markers, including $2.3 \%$ positive for hepatitis $B$ core antibody and $e$ antibody which is a pattern indicating possible virus $\mathrm{B}$ carrier. Furthermore, $32.3 \%$ of them presented with hepatitis B core antibody which, according to some authors, could be an indirect marker of chronic carriers of non-A, non-B hepatitis. ${ }^{8}$ Therefore, screening with third generation methods for hepatitis B surface antigen alone is not sufficient to prevent post-transfusion hepatitis $B$ virus infection.

The probability of coming into contact with hepatitis B virus increases in direct proportion to the number of transfusions, and thus age: in fact all the thalassaemic children over the age of 12 years were positive for one or more hepatitis B markers. The fact that the older patients were all positive for hepatitis B markers could, however, be partly historical. In other words, it seems that our patients all come into contact with hepatitis B virus but the infectivity must be generally so low that it does not result in hepatitis, although it causes seroconversion.

Of particular interest are the episodes of acute hepatitis in 32 patients shown by the serial study of the transaminase activities.

For our patients the risk of contracting hepatitis B was clearly higher than that reported in other series of multitransfused subjects, even though it has reduced noticeably in past years. ${ }^{9}$ In the present study there were 23 episodes of hepatitis B attributable to non-A, non-B virus-about $75 \%$ of the episodes observed. This percentage is lower than that reported by other authors in series of multitransfused subjects in the USA, Italy, and Australia. ${ }^{5} 910$

We also showed the possibility of double infection since one patient presented two episodes of increased activities of transaminases, separated by an interval of nine months. The first increase was associated with negativity to all the hepatitis virus markers and was attributable to non-A, non-B hepatitis; the second, in which the specific IgM values were positive, was attributable to cytomegalovirus hepatitis.

The sustained increase in the transaminase activities may be partly explained by the histologic pictures of chronic aggressive hepatitis described previously by some of us. ${ }^{11}$ It is probable, however, that pictures of chronic hepatitis are produced by hepatitis B virus only exceptionally; most patients have a chronic hepatitis non-A, non-B, although it is not excluded that the iron overload is responsible for the persistence of chronic inflammatory disease even in cases with optimal hepatitis B virus clearance. ${ }^{12-13}$

In conclusion, early hepatitis $B$ vaccination of thalassaemic children could prevent hepatitis $B$ virus infection. Furthermore, more careful selection of blood donors, excluding from donation those implicated in episodes of post-transfusion hepatitis, will help to prevent non-A, non-B virus infection. ${ }^{14}$

\footnotetext{
References

' Papaevangelou G, Frösner G, Economidou J, Parcha S, Roumeliotou A. Prevalence of hepatitis A and B infections in multiply transfused thalassaemic patients. Br Med J 1978;i:689691.

2 Economidou J, Costantoulakis M, Taylor PE. The incidence of hepatitis associated antigen and antibody in patients with thalassaemia in Greece. Vox Sang 1970;19:401-3.

${ }^{3}$ Stevens CE, Silbert JA, Szmuness W. Serologic evidence of hepatitis $A$ and $B$ virus infection in thalassaemia patients. Retrospective study. Transfusion 1978;18:356-61.

4 Alter HJ, Purcell RH, Holland PV, Alling DW, Koziol DE. Donor transaminase and recipient hepatitis. Impact on blood transfusion services. JAMA 1981;246:630-4.

${ }^{5}$ Cossart YE, Kirsch S, Ismay SL. Post-transfusion hepatitis in Australia. Report of the Australian Red Cross study. Lancet 1982;i:208-13.

${ }^{6}$ Masera G, Jean G, Gazzola G, Novakova M. Role of chronic hepatitis in development of thalassaemic liver disease. Arch Dis Child 1976;51:680.

${ }^{7}$ Masera G, Jean G, Conter V, Terzoli S, Mauri SA, Cazzaniga M. Sequential study of liver biopsy in thalassaemics Arch Dis Child 1980;5:800-2.
} 
${ }^{8}$ Tabor E, Hoofnagle JH, Barker LF, et al. Antibody to hepatitis B core antigen in blood donors with history of hepatitis. Transfusion 1981;21:366-71.

9 Tremolada F, Chiappetta P, Noventa F, Valfré C, Ongaro G, Realdi G. Prospective study of posttransfusion hepatitis in cardiac surgery patients receiving only blood or also blood products. Vox Sang 1983;44:25-30.

10 Tremolada F, Realdi G, Noventa F, et al. Post-transfusion hepatitis in Italy. Lancet 1982;i:853-4.

11 Jean G, Terzoli S, Mauri R, et al. Cirrhosis associated with multiple transfusions in thalassaemia. Arch Dis Child 1984;59:67-70.

12 Pastore G, Tannoia N, Angarano G, et al. Chronic liver hepatitis in thalassaemic liver disease Vox Sang 1983;44:14-24.
13 Realdi G, Alberti A, Rugge M et al. Long term follow-up of acute non-A non-B post-transfusion hepatitis: evidence of progression to liver cirrhosis. Gut 1982;23:270-5.

14 Nath N, Pielech M, Dodd RY. Hepatitis associated marhers in the American Red Cross blood donor population. Vox Sang $1983 ; 44: 312-8$.

Correspondence to Dr G Piacentini, Divisione de Pediatria, Nuovo Ospedale S Gerardo, Via Donizetti, 106, 20052 Monza (Milano), Italy.

Received 2 August 1984. 